\title{
Management of emergent hypertension in Herat Regional Hospital, Afghanistan
}

\author{
MN Faqiryar \\ From 23rd World Congress of the World Society of Cardio-Thoracic Surgeons \\ Split, Croatia. 12-15 September 2013
}

\begin{abstract}
Background
Hypertensive emergency is an emergent case which all prompt consideration should be taken. Due to control of hypertension less cases of emergent hypertension is seen nowadays; so the data from April 2012 to Dec 2012 in internal ward of the regional hospital shows 305 cases (113 males and 192 females) recorded aged between 16 - 90 years with the average of 49 years. Number of admitting days in hospital was between 2 to 6 days. The mean rate days of hospitalization were 3 days. Although blood pressure is usually strikingly elevated (diastole pressure $>130 \mathrm{mmHg}$ ) emergency include hypertensive encephalopathy, hypertensive nephropathy, intra cranial hemorrhage, aortic dissention, preeclampsia, eclampsia, pulmonary edema, unstable angina or MI.
\end{abstract}

\section{Methods}

The goal of treatment in emergent hypertensive is to reduce BP no more than $25 \%$ within an hour and forward the BP to $160 / 100 \mathrm{mmHg}$ within 2-6 hours to avoid the risk of serious morbidity or death.

The IV medications for hypertensive emergencies are available in our hospital are;

1. Labetalol: $20 \mathrm{mg} / 2$ minutes bolus then $40-80 \mathrm{mg}$ at 10 minutes interval up to $300 \mathrm{mg}$ total. Infusion $2 \mathrm{mg} /$ minutes until satisfactory result occurs.

2. Hydralazine: $10-15 \mathrm{mg}$ at 30 minutes interval.

3. Furosemide: $20-40 \mathrm{mg}$.

\section{Result}

1. Unfortunately injection of Nitroprusside, Enaloprilat, Nicardipine and Nitroglycerin are not available.

2. 190 cased discharged with oral antihypertensive drugs.

Correspondence: dr_nabil01@yahoo.com

Herat Regional Hospital, Herat City, Afghanistan
3. 16 cases died.

4. 15 cases referred to abroad.

5. 84 cases left hospital without prior permission.

6. Unfortunately half of the cases come to hospitals when CVA or TIA occurs.

\section{Conclusion}

1. Due to insufficient system of data collecting, I have fewer tips about the prognosis of the patients.

2. The only IV antihypertensive drugs we have are Labetalol and Hydralazine.

3. If we were supplied with other IV antihypertensive drugs, we surly can get good results.

4. Unfortunately poor prognosis is seen in elderly hypertensive patients.

Published: 11 September 2013

doi:10.1186/1749-8090-8-S1-0253

Cite this article as: Faqiryar: Management of emergent hypertension in Herat Regional Hospital, Afghanistan. Journal of Cardiothoracic Surgery 2013 8(Suppl 1):O253.

Submit your next manuscript to BioMed Central and take full advantage of:

- Convenient online submission

- Thorough peer review

- No space constraints or color figure charges

- Immediate publication on acceptance

- Inclusion in PubMed, CAS, Scopus and Google Scholar

- Research which is freely available for redistribution
C Biomed Central

(c) 2013 Faqiryar; licensee BioMed Central Ltd. This is an Open Access article distributed under the terms of the Creative Commons Attribution License (http://creativecommons.org/licenses/by/2.0), which permits unrestricted use, distribution, and reproduction in any medium, provided the original work is properly cited. 